\title{
Challenges of analyzing the global trade in CITES-listed wildlife
}

*Janine E. Robinson, Janine.robinson82@gmail.com, Durrell Institute of Conservation and Ecology, School of Anthropology and Conservation, Marlowe Building, University of Kent, Canterbury, Kent, CT2 7NR, UK

Pablo Sinovas, pablo.sinovas@unep-wcmc.org, UN Environment World Conservation Monitoring Centre, 219 Huntingdon Road, Cambridge CB3 0DL, United Kingdom

*corresponding author

Article Impact statement: Better understanding and interpretation of CITES trade data is required to avoid erroneous conclusions in publications about wildlife trade.

\section{Running head: CITES data}

Key words: Convention on International Trade in Endangered Species, conservation, wildlife trade, CITES Trade Database, legislation, import, export

International wildlife trade can represent a major threat to biodiversity conservation. Annually, billions of plants, animals and their products are traded across international borders, with legal trade alone estimated to be worth over 320 billion USD per annum (TRAFFIC 2009). CITES, the Convention on International Trade in Endangered Species of Wild Fauna and Flora, regulates and monitors trade in $\sim 35,000$ species. CITES has 183 signatory countries ('Parties'), all of which must provide annual reports detailing their international trade in CITES-listed species, culminating in more than 18 million trade records. This wealth of data, reported from 1975 to-date, is maintained in a central, freelyaccessible database, the 'CITES Trade Database' (trade.cites.org), managed by the UN Environment World Conservation Monitoring Centre (UNEP-WCMC) on behalf of the CITES Secretariat. In recent years, many scientists have utilized this database to try to understand the wildlife trade, and its implications for conservation of threatened species, resulting in at least 114 peer-reviewed

This article has been accepted for publication and undergone full peer review but has not been through the copyediting, typesetting, pagination and proofreading process, which may lead to differences between this version and the Version of Record. Please cite this article as doi: $\underline{10.1111 / \text { cobi.13095. }}$.

This article is protected by copyright. All rights reserved. 
publications (Supporting Information). However, given the vast and international nature of the dataset, properly interpreting the data is highly complex, and incorrect interpretation can lead to erroneous conclusions. This is of conservation relevance, particularly as such studies may form the basis for management decisions and recommendations. The 'Guide to Using the CITES Trade Database' (UNEP-WCMC 2013) provides technical instruction on utilizing the database. However, here we discuss major challenges of analyzing and interpreting CITES trade data, highlight common areas of confusion arising in the scientific literature, and provide guidance on how these can be avoided.

\section{General analyses of CITES trade data}

Various studies have sought to understand trade dynamics of CITES-listed species (e.g. Carpenter et al. 2014; Li \& Jiang 2014). However, numerous factors affect trade dynamics, including (amongst others); countries joining CITES at different times (contributing data from different periods), new/amended CITES listings, taxonomic changes and national and international regulatory interventions (e.g. quotas, suspensions). Therefore taking the trade data at face value can sometimes be misleading. Figure 1 (a) illustrates a sharp increase in reptiles imported to the EU since 2006. However, closer interpretation reveals that this is caused by the inclusion on Appendix III of a previously unlisted genus, whose trade prior to this time was simply not reported because it was not CITES-listed.

Whilst some factors affecting trade can be cross-checked utilizing resources including the CITES website and the Species+ database (www.speciesplus.net), it can often be complex, or there is simply insufficient information, to reliably identify specific drivers of trends. This emphasises the need for careful interpretation of the CITES data. Below we highlight four key areas we feel require further consideration in future studies.

\section{Importer vs exporter reported figures}

Countries provide data for both their imports and exports, resulting in two data sources for any data query; 1) that reported by importing countries, and 2) that reported by exporting countries. For several reasons, these do not always match. Whilst data in annual reports should be based on trade that actually took place (Annex to CITES Notification 2017/007), sometimes countries report data based

This article is protected by copyright. All rights reserved. 
on permits issued. As the quantities actually traded may be lower than those permitted, this can result in lower importer-reported trade levels. On this basis, some studies have analyzed data reported predominantly by importing countries (e.g. Rhyne et al. 2012). However, countries are not required under CITES to issue import permits for Appendix II species (although several do as part of stricter domestic measures), and therefore imports of Appendix II species will not always be reported. Figure 1(b) illustrates how under-reporting of imports can lead to substantially higher trade levels reported by exporters than by importers. Where it is important to understand quantities that export countries have authorized, or when the completeness and accuracy of reporting is considered higher by exporters, it may be more appropriate to use exporter-reported data.

Other reasons for inconsistencies in import and export figures include different use of trade 'terms' such as 'source', 'purpose', 'unit' etc. (see Table 1 and UNEP-WCMC 2013), whereby different Parties apply the 'terms' differently. Additionally, export permits issued at the end of the year may not be used (and not reported) by importing countries until the following year, leading to discrepancies between years. Finally, data reported by both importers and exporters may be subject to reporting errors, and therefore neither indicates actual minimum or maximum numbers in trade as indicated in Fialho et al. 2016 and Foster et al. 2014. Where possible, both should be considered, as the existence of discrepancies is in itself information that may reveal aspects of interest.

\section{2. 'Comparative' vs 'Gross'/'Net' trade reports}

Trade data can be downloaded as 'comparative' or 'gross/net' trade reports, the choice of which requires careful consideration. In general, 'comparative' reports provide the most comprehensive picture of the trade, as they present imports, exports, re-exports, and all trade 'terms', as reported by both importing and exporting countries, allowing side-by-side comparison.

'Gross' and 'net' reports provide more simplified data summaries, excluding information on source, purpose and country of origin, but can overestimate trade. Gross reports combine both exports and re-exports of traded specimens, thereby often double counting individuals. Re-exports can be identified by their country of origin, which will differ from the country of export. In the database, direct trade can be isolated by selecting data with no origin country listed indicating that the exporting country is its origin. Rivalan et al. (2007) use gross reports to assess the effect of trade bans, but as

This article is protected by copyright. All rights reserved. 
this includes re-exports and details are not provided regarding the source of specimens (e.g. wild or captive-bred), the analysis may not provide an accurate picture of the trade or of shifts in reported sources that may occur following trade bans. Instead, for research questions aiming to consider actual numbers in trade, 'net' reports account for double counting by reporting the difference between gross exports and gross imports. However, where discrepancies exist between importers and exporters, gross and net reports both take the larger value, and therefore net reports can also inflate trade figures, albeit by a lesser amount.

Regardless of the report type, a misconception is that each row in the data represents an individual shipment/trade transaction (e.g. as in D'Cruze \& Macdonald 2015), which is not the case. All data for the year, concerning the same taxa, exporter, importer and trade terms are aggregated into one row (see UNEP-WCMC 2013).

\section{Terms and units}

CITES regulates trade in whole animals and plants as well as their parts and derivatives. The different commodities in trade are defined by standardised 'terms' (Table 1), which can in turn be reported in different 'units' (e.g. number of specimens, kilograms), and many of these terms and units cannot be meaningfully summed in one analysis. For example, Jiang et al. (2013) summarise China's trade in Ptyas mucosus as 'number of pieces/specimens', but the figures presented combine 'terms' such as live animals with parts such as leather products. Additionally, Mieres \& Fitzgerald (2006) provide figures of Tupinambis trade that result from the addition of number of skins with $\mathrm{kg}$ and $\mathrm{cm}$ of skins. Units should not be combined unless they can be directly converted (e.g. grams to kilograms) or conversion rates are available (e.g. kilograms to cubic meters based on known density) (e.g. ArroyoQuiroz et al. 2007).

\section{Purpose codes}

Confusion has arisen in the literature over the use of purpose codes, which can be particularly challenging. For example, trade for 'personal' purposes is often used for non-commercial movement of pets (e.g. holidays, emigration), but this excludes large numbers traded for the pet trade, which are traded as 'commercial'. Indeed, Harrington (2015) demonstrates that ten times the number of 
carnivores and primates are traded as 'commercial' than 'personal', and Robinson et al. (2015) report that $99.2 \%$ of Appendix II live reptiles are traded as 'commercial'. Consequently, in seeking to understand global trade in exotic pets, the data in Bush et al. (2014) are only representative of a tiny fraction of the trade because only transactions traded as 'personal' were used. In addition, CITES 'purpose' categories are used for multiple types of trade and can overlap. So, whilst 'commercial' encompasses specimens traded for the commercial pet trade, specimens supplying research facilities or zoos, for example, may also be traded as 'commercial' by some countries, even though alternative codes can also be used (e.g. 'scientific' and 'zoo', respectively).

The use of 'purpose' 'hunting trophy', often used in combination with a variety of 'terms' (e.g. body, skin, skull), can also result in confusion because a specific 'trophy' 'term' also exists, which is sometimes used in combination with 'purposes' different from 'hunting trophy'. Consequently, an analysis that only uses the 'term' 'trophy' but discounts other 'terms' with 'purpose' 'hunting trophy' (e.g. Di Minin et al. 2016) may underestimate trade. In addition, different parts of an animal (e.g. skin, skull, feet and horns) are sometimes reported as separate trophy items, which if incorrectly interpreted can lead to overestimates of the number of animals.

\section{Conclusion}

The CITES Trade Database provides a powerful tool for understanding the wildlife trade for listed species, but it must be carefully analyzed and interpreted. Additionally, as with all data sources, there are limitations relating to the use of CITES trade data, and therefore we recommend users refer to the database guidelines and wider literature for further discussion (e.g Thomas et al. 2006; Herrel \& van der Meijden, 2014; Lopes et al. 2017). Notwithstanding, the database provides an unparalleled tool for monitoring trade in wildlife and wildlife products across borders, and with more than one million records added annually in recent years, it represents an invaluable resource with enormous potential for understanding global wildlife trade.

Acknowledgements: We sincerely thank J Bicknell, D Roberts and N Burgess for discussion and comments on earlier versions of this manuscript.

This article is protected by copyright. All rights reserved. 


\section{Literature Cited}

Arroyo-Quiroz I, Pérez-Gil R, Leader-Williams L. 2007. Mexico in the international reptile skin trade: a case study. Biodiversity and Conservation 16:931-952.

Bush ER, Baker SE, Macdonald DW. 2014. Global trade in exotic pets 2006-2012. Conservation Biology 28:663-676.

Carpenter Al, Andreone F, Moore RD, Griffiths RA. 2014. A review of the international trade in amphibians: the types, levels and dynamics of trade in CITES-listed species. Oryx 48:565-574.

D'Cruze N, Macdonald DW. 2015. Clouded in mystery: the global trade in clouded leopards.

Biodiversity and Conservation 24:3505-3526.

Di Minin E, Leader-Williams N, Bradshaw CJ. 2016. Banning trophy hunting will exacerbate biodiversity loss. Trends in Ecology and Evolution 31:99-102.

Fialho SM, Ludwig G, Valença-Montenegro MM. 2016. Legal international trade in live neotropical primates originating from South America. Primate Conservation 30:1-6.

Foster S, Wiswedel S, Vincent A. 2014. Opportunities and challenges for analysis of wildlife trade using CITES data - seahorses as a case study. Aquatic Conservation: Marine and Freshwater Ecosystems 26:154-172.

Harrington LA. 2015. International commercial trade in live carnivores and primates 2006-2012: response to Bush et al. 2014. Conservation Biology 29:293-296.

Herrel A, van der Meijden A. 2014. An analysis of the live reptile and amphibian trade in the USA compared to the global trade in endangered species. Herpetological Journal 24:103-110.

Jiang Z, Zhou Z, Meng Z, Meng X, Li L, Ping X, Zeng Y, Mallon DP. 2013. Domestic and CITES regulations controlling the international snake trade in China. Oryx 47:532-534.

Li L, Jiang Z. 2014. International trade of CITES listed bird species in China. PLoS ONE 9(2): e85012.

This article is protected by copyright. All rights reserved. 
Lopes RJ, Ferreira JM, Moraes-Barros N. 2017. A critical comment to D'Cruze and Macdonald 2016. Nature Conservation 21:159.

Mieres MM, Fitzgerald LA. 2006. Monitoring and managing the harvest of tegu lizards in Paraguay. Journal of Wildlife Management 70:1723-1734.

Rhyne AL, Tlusty MF, Kaufman L. 2012. Long-term trends of coral imports into the United States indicate future opportunities for ecosystem and societal benefits. Conservation Letters 5:478-485.

Rivalan P, Delmas V, Angulo E, Bull LS, Hall RJ, Courchamp F, Rosser AM, Leader-Williams N. 2007. Can bans stimulate wildlife trade? Nature 447:529-530.

Robinson JE, Griffiths RA, St. John FAV, Roberts DL. 2015. Dynamics of the global trade in live reptiles: Shifting trends in production and consequences for sustainability. Biological Conservation $184: 42-50$

Thomas PO, Albert MR, Blundell, AG, Mascia MB. 2006. Data on wildlife trade. Conservation Biology, 20: $597-599$.

TRAFFIC. 2009. Wildlife Trade. http://www.traffic.org/trade (accessed January, 2017).

UNEP-WCMC. 2013. A guide to using the CITES Trade Database. Version 8. United Nations Environment Programme-World Conservation Monitoring Centre. Cambridge, UK.

Table 1. Selection criteria and options when downloading data from the CITES Trade Database.

Selection criteria options

Year range

Country

Source

Purpose

Term

Taxon
1975 - year before present

all CITES Party countries (export and/or import)

10 sources including 'wild', 'ranched', 'captive bred'

12 purposes including 'commercial', 'personal', 'scientific'

118 terms including 'live', 'skins', 'carvings'

Kingdom through to subspecies

This article is protected by copyright. All rights reserved. 
* For a full description and explanation of criteria refer to UNEP-WCMC 2013.

Figure 1 (a). Imports into the EU of live wild-sourced CITES-listed reptiles between 1996 and 2008. The sharp increase in reptile imports between 2006 and 2008 is due to the new listing of the genus (Graptemys spp.) on Appendix III of CITES in 2006. The new listing, and hence reporting requirement for this genus since 2006, gives the impression of an increase in reptile trade 'per se', but if this genus is excluded from the data, trade in all other reptiles appears to be actually decreasing (b) the discrepancy between importer and exporter reported trade in Appendix II-listed Ara ararauna is due to South Africa beginning to report exports in large numbers of captive bred birds to West Asian countries, with this trade largely unreported by those countries.

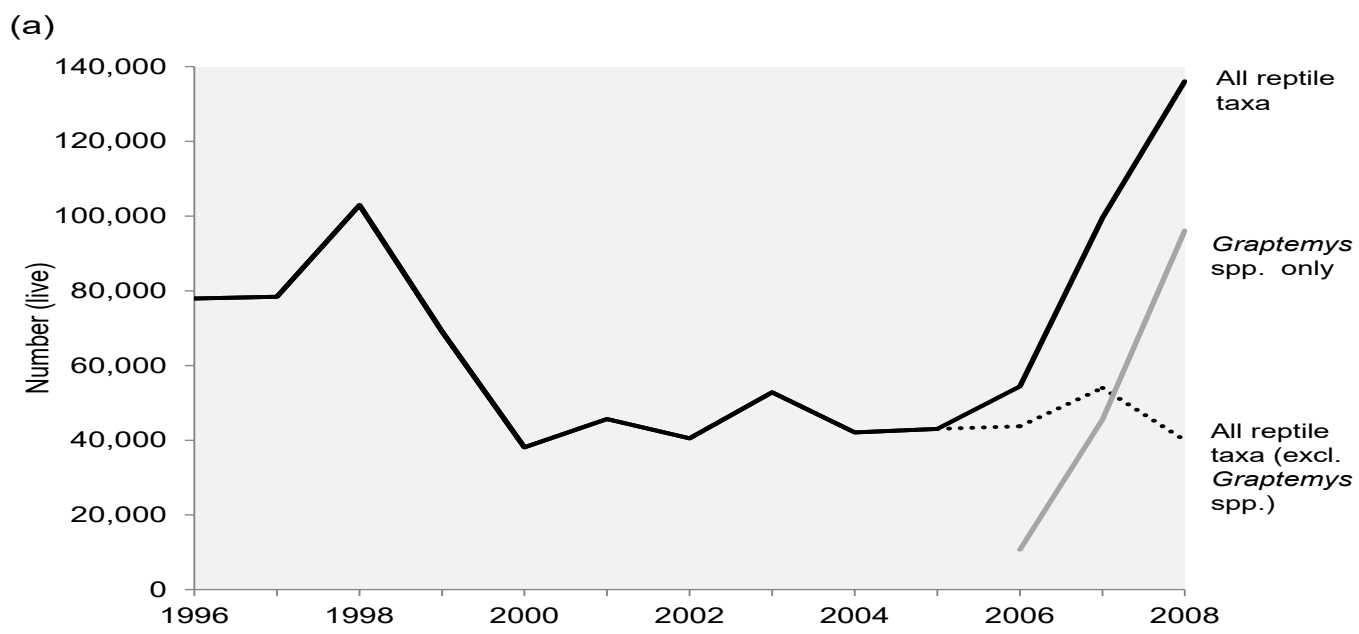

(b)

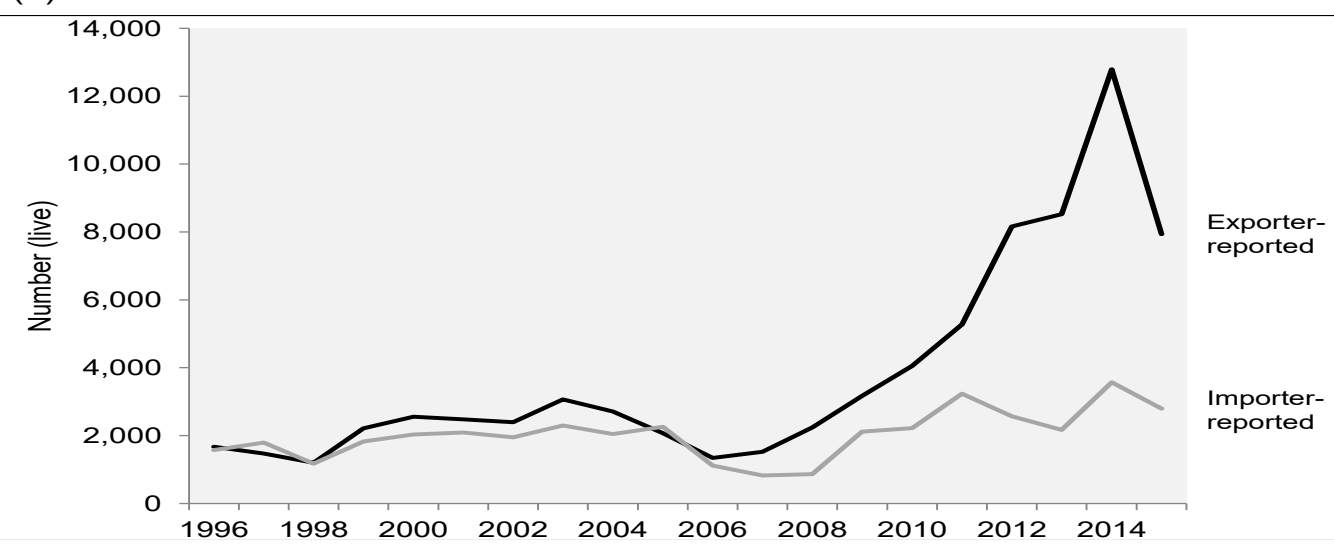

This article is protected by copyright. All rights reserved. 